\title{
Observations on biological properties of the chub, Leuciscus cephalus and environment conditions in the Çaparlıpatlak Pond (Balikesir), Southern Marmara Region, Turkey
}

\author{
Hatice Torcu Koç*, \\ Zeliha Erdoğan, \\ Kazım Bulgen \\ Department of Biology, \\ Faculty of Science and Arts, \\ University of Balikesir University, \\ Cagis Campus, 10145 Balikesir, Turkey
}

\begin{abstract}
This investigation was conducted in the Çaparlipatlak Pond, based on a 1-year study involving 431 specimen. The age composition of this species ranged between I and VI with the dominance of fourth age group in the population. Individuals were composed of $36.60 \%$ males and $63.40 \%$ females. The male and female ratio was 1:1.71 (M:F). Female individuals attained greater size than males. The largest female captured was $21.5 \mathrm{~cm}$ FL while the largest male was $20.2 \mathrm{~cm}$ FL at the same age, VI. The lengthweight relationship was given by $\mathrm{W}=0.0648 \cdot \mathrm{L}^{2.44}$ (where $\mathrm{W}=$ weight in $\mathrm{g} ; \mathrm{FL}=$ fork length in $\mathrm{mm}$ ). Age at length data were inferred by modal analysis of the length-frequency distributions. The parameters of the fitted Von Bertalanffy growth equation were $\mathrm{L} \infty=23.66 \mathrm{~cm} ; \mathrm{K}=0.30 \mathrm{yr}^{-1}$; to $=-0.95 \mathrm{yr}$. Macroscopic examination of the gonads, and analysis of the monthly values of the gonadosomatic index indicated that reproduction occurs in spring and early summer, with a maximum between April and June, when water temperatures are high.
\end{abstract}

Key words: Leuciscus cephalus, age, growth, condition, spawning

\section{INTRODUCTION}

The chub Leuciscus cephalus (L.) is widely distributed in Europe, Anatolia, Black and Azov Sea basins (Geldiay and Balik, 2007; Kuru, 2000). The chub is an opportunistic and mobile species and is common in almost all running waters in Turkey (Bogutskaya, 1997). Although age, growth, feeding, length-weight relationships and reproduction features of the chub inhabiting Europen and Turkish waters have been reported (Karataş

\footnotetext{
* Corresponding author. E-mail: htorcu@balikesir.edu.tr
}

and Akyurt, 1997; Gül and Yılmaz, 2002; Saş1 and Balık, 2003; Balık et al., 2004; Kalkan et al., 2005; Hamwi et al., 2005; Koc et al., 2007), little is known as to biology in Turkish reservoirs such as the Eaparlzipatlak Pond, where chub is mainly caught for consumption and thus has an economic value. It is also a popular game fish. This paper describes various aspects of the biology of a Çaparlipatlak Pond population of L. cephalus in the vicinity of Balikesir (Turkey).

Boron accumulation is not often studied for aquatic and semi-aquatic organisms except in a 
few papers (Emiroglu et al., 2010). In the future, we also aim to investigate boron concentration of Çaparlipatlak Pond, its sediment and L. cephalus and different organisms from surrounding county of Balikesir.

\section{MATERIALS AND METHODS}

Çaparlipatlak Pond (the surface area 637 decares, depth $6.2-19.16 \mathrm{~m}$ ) is being fed by Salkım and Agu Creeks of Koca River, situated at forthy-five $\mathrm{km}$ from Balikesir city center and at $233 \mathrm{~m}$ above sea level. It was built in 1992 by 17th Regional Directorate of Rural Services to supply irrigation water for the city of Balikesir (Fig. 1).

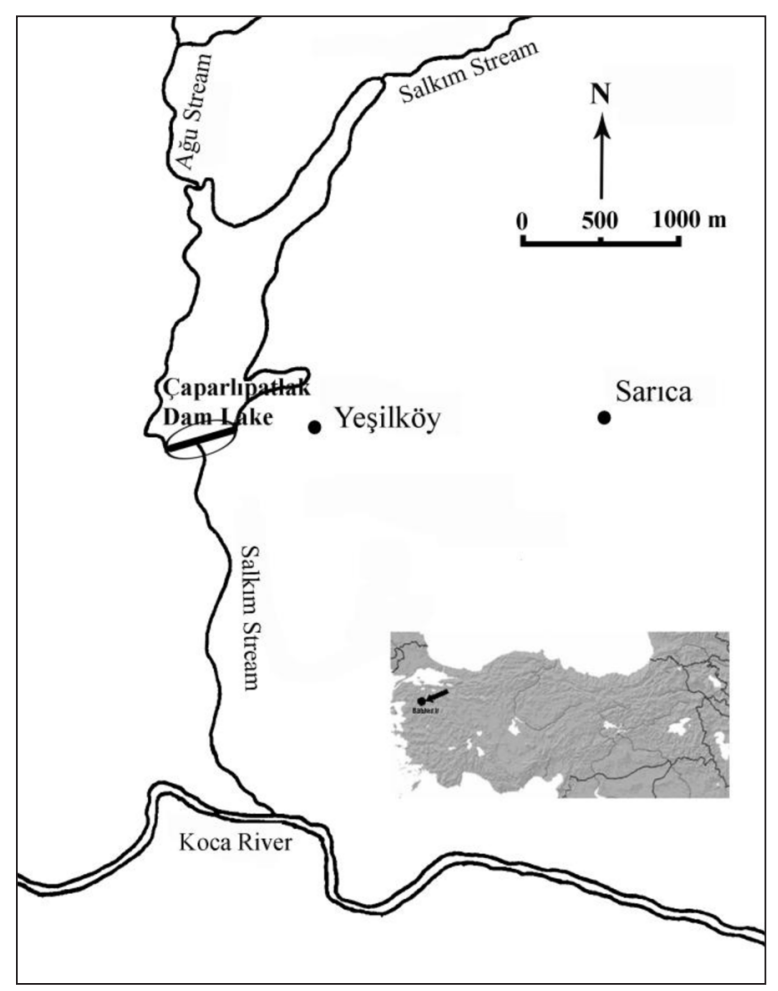

Fig. 1. The studying area

A total of 431 chub (272 females and 159 males) were monthly caught with various mesh gillnets during the period from January 2005 to December 2005. Each specimen was measured (fork length, FL, to the nearest $\mathrm{mm}$ below), weighed (total wet weight, TW, in g) at the laboratory at Balikesir University. Scales which were taken from the left side of the fish above the lateral line were used for determining age, especially due to difficulty of otolith interpretation (Bagliniere and Le Louarn, 1987). Von Bertalanffy growth equations were calculated according to: $\left.\mathrm{L}_{\mathrm{t}}=\mathrm{L}_{\infty}\left[1-\mathrm{e}^{-\mathrm{k}(\mathrm{t}-\mathrm{t})}\right)\right]$ in the length and $\mathrm{W}_{\mathrm{t}}=\mathrm{W}_{\infty}\left[1-\mathrm{e}^{-\mathrm{k}(\mathrm{t}-\mathrm{t})}\right]_{0}^{\mathrm{b}}$ in weight (Sparre and Venema, 1992). The fork length-weight relationships were calculated for male, female and all individuals:

$$
\mathrm{W}=\mathrm{a} \mathrm{FL}^{\mathrm{b}}
$$

Condition coefficients $(\mathrm{CF})$ were calculated for both sexes using the equation $\mathrm{CF}=$ (Body weight/Fork Length ${ }^{3}$. 100) (Ricker, 1975). Each of these was sexed by macroscopic observation of the gonads, which were removed and weighed (gonad weight, GW, in g). The overall sex ratio and stages of sexual maturity were also determined. The spawning period was determined by means of the monthly changes in the gonadosomatic index (GSI), the gonadosomatic index was calculated using the following equation: GSI = Gonad weight $/$ (Body weight-gonad weight) 100 (Avsar, 2005).

\section{RESULTS AND DISCUSSION}

Table 1 shows the length-weight distributions of male, female and sexed individuals. There is not a statistically significant difference in average fork length and weight between males and females. The length-weight relationships were calculated for each sex separately as given below:

$\mathrm{W}=0.0765 \cdot \mathrm{L}^{2.38}\left(\mathrm{n}=272 ; \mathrm{r}^{2}=0.85\right)$ for females and $\mathrm{W}=0.04442 \cdot \mathrm{L}^{2.58}\left(\mathrm{n}=159 ; \mathrm{r}^{2}=0.80\right)$ for males and showed a negative allometric growth with in the length range of 8.0$21.5 \mathrm{~cm}$ (Figs. 2 and 3). The ages of captured fish ranged between I and VI, and III age group was dominant in the population ( $\mathrm{Ta}$ ble 1). Because of selectivity of nets, the fish of 0 age group was not represented in the specimens. There were $36.60 \%$ males and $63.40 \%$ females, the sex ratio (M:F) (1:1.71) was significantly different from 1.1 ( $\mathrm{p}<0.05)$ (Fig. 4). 
Table 1. Mean fork length (FL, cm) and mean weight (W, g), standard error (SE) for different age groups of Leuciscus cephalus males, females, and combined sexes

\begin{tabular}{|c|c|c|c|c|c|c|c|c|c|}
\hline \multirow{2}{*}{$\sum_{4}^{\infty}$} & \multirow{2}{*}{$\mathrm{N}$} & \multicolumn{2}{|c|}{ Male + Female } & \multirow{2}{*}{$\mathrm{N}$} & \multicolumn{2}{|c|}{ Male } & \multirow{2}{*}{$\mathrm{N}$} & \multicolumn{2}{|c|}{ Female } \\
\hline & & $\mathrm{FL} \pm \mathrm{SE}(\mathrm{cm})$ & $\mathrm{W} \pm \mathrm{SE}(\mathrm{g})$ & & $\mathrm{FL} \pm \mathrm{SE}(\mathrm{cm})$ & $\mathrm{W} \pm \mathrm{SE}(\mathrm{g})$ & & $\mathrm{FL} \pm \mathrm{SE}(\mathrm{cm})$ & $\mathrm{W} \pm \mathrm{SE}(\mathrm{g})$ \\
\hline I & 35 & $\begin{array}{c}9.63 \pm 0.13 \\
(8.0-10,8)\end{array}$ & $\begin{array}{l}16.20 \pm 0.67 \\
(9.98-27.57)\end{array}$ & 11 & $\begin{array}{c}9.82 \pm 0.25 \\
(8.1-10.8)\end{array}$ & $\begin{array}{l}15.75 \pm 1.33 \\
(9.98-23.21)\end{array}$ & 24 & $\begin{array}{c}9.55 \pm 0.15 \\
(8.2-10.6)\end{array}$ & $\begin{array}{c}16.40 \pm 0.8 \\
(11.47-27.57)\end{array}$ \\
\hline II & 84 & $\begin{array}{c}13.62 \pm 0,07 \\
(12.1-15.0)\end{array}$ & $\begin{array}{c}38.47 \pm 0.73 \\
(14.72-51.32)\end{array}$ & 33 & $\begin{array}{l}13.71 \pm 0,10 \\
(12.2-14.9)\end{array}$ & $\begin{array}{c}38.82 \pm 1,17 \\
(14.72-51.32)\end{array}$ & 51 & $\begin{array}{c}13.57 \pm 0.09 \\
(12.1-15.0)\end{array}$ & $\begin{array}{c}38.23 \pm 0.94 \\
(18.79-50.33)\end{array}$ \\
\hline III & 166 & $\begin{array}{c}14.41 \pm 0.04 \\
(13.4-15.4)\end{array}$ & $\begin{array}{c}45.69 \pm 0.6 \\
(29.00-73.04)\end{array}$ & 75 & $\begin{array}{c}14.42 \pm 0.07 \\
(13.5-15.4)\end{array}$ & $\begin{array}{c}44.85 \pm 0.81 \\
(33.52-68.38)\end{array}$ & 91 & $\begin{array}{c}14.41 \pm 0.05 \\
(13.4-15.3)\end{array}$ & $\begin{array}{c}46.31 \pm 0.85 \\
(29.00-73.04)\end{array}$ \\
\hline IV & 94 & $\begin{array}{c}15.46 \pm 0.05 \\
(14.5-16.0)\end{array}$ & $\begin{array}{c}51.45 \pm 0.6 \\
(15.41-66.50)\end{array}$ & 30 & $\begin{array}{c}15.38 \pm 0.08 \\
(14.5-16.4)\end{array}$ & $\begin{array}{c}51.36 \pm 1.05 \\
(35.60-63.82)\end{array}$ & 64 & $\begin{array}{c}15.51 \pm 0.06 \\
(14.5-16.6)\end{array}$ & $\begin{array}{c}51.51 \pm 0.76 \\
(15.41-66.50)\end{array}$ \\
\hline $\mathrm{V}$ & 38 & $\begin{array}{c}17.19 \pm 0.17 \\
(16.5-18.2)\end{array}$ & $\begin{array}{c}66.49 \pm 2.53 \\
(46,37-100,9)\end{array}$ & 10 & $\begin{array}{c}17.03 \pm 0.10 \\
(16.7-17.6)\end{array}$ & $\begin{array}{c}64.60 \pm 3.61 \\
(49.01-85.52)\end{array}$ & 28 & $\begin{array}{c}17.05 \pm 0.10 \\
(16.5-18.2)\end{array}$ & $\begin{array}{c}67.99 \pm 2.57 \\
(46.37-100.90)\end{array}$ \\
\hline VI & 14 & $\begin{array}{c}19.51 \pm 0.30 \\
(18.0-21.5)\end{array}$ & $\begin{array}{l}100.92 \pm 2.98 \\
(84.36-120.9)\end{array}$ & 5 & $\begin{array}{c}19.60 \pm 0.20 \\
(19.0-20.2)\end{array}$ & $\begin{array}{c}99.21 \pm 4.56 \\
(84.36-110.00)\end{array}$ & 9 & $\begin{array}{c}19.46 \pm 0.47 \\
(18.0-21.5)\end{array}$ & $\begin{array}{c}101.86 \pm 4.04 \\
(86.83-120.9)\end{array}$ \\
\hline & 431 & & & 159 & & & 272 & & \\
\hline
\end{tabular}

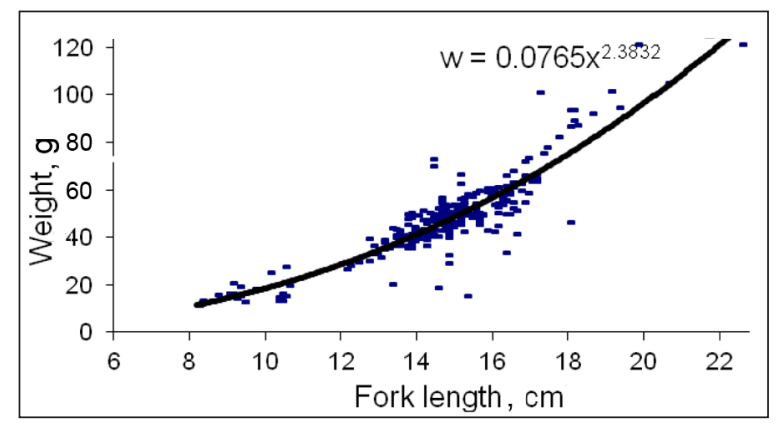

Fig. 2. Length-weight relationship of L. cephalus (female)

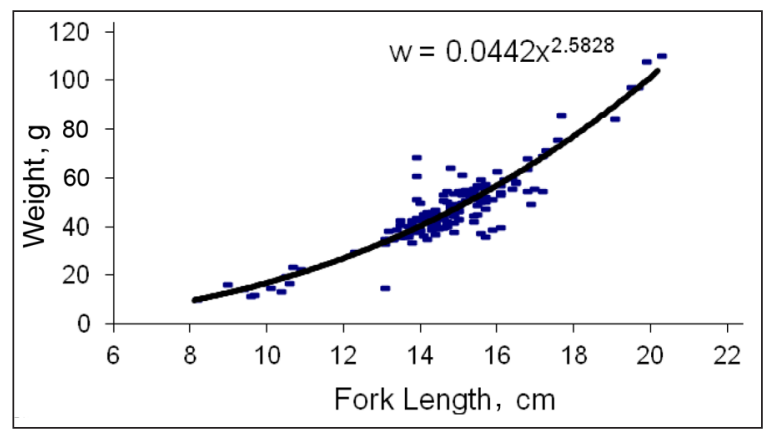

Fig. 3. Length-weight relationship of L. cephalus (male)
The equation of theoretical growth in length of the chub in the Çaparlipatlak Pond is as follows: $\mathrm{L} \infty=23.66\left(1-\mathrm{e}^{-0.301(t+0.953)}\right)$. The seasonal variations in the condition coefficients were determined for both sexes (Fig. 5). In general, monthly conditions showed a similiar pattern for both sexes, showing higher in the spawning period, but lower after the spawning period and during the the winter period. Monthly changes in gonadosomatic index for all individuals are shown in Fig. 6. Spawning

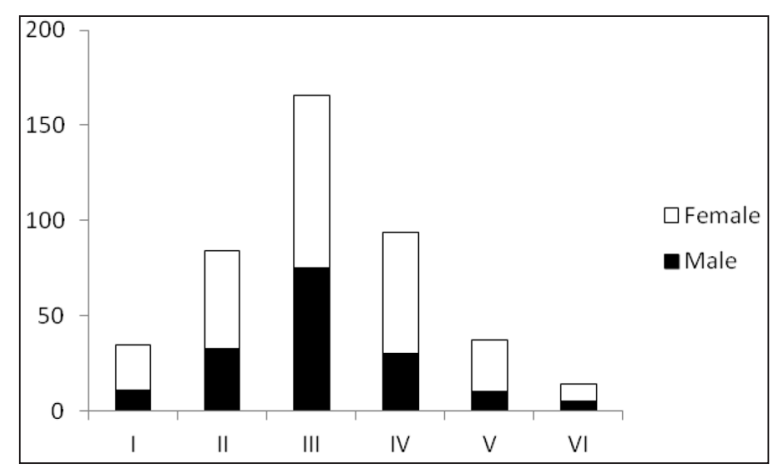

Fig. 4. Sex and age composition of L. cephalus 


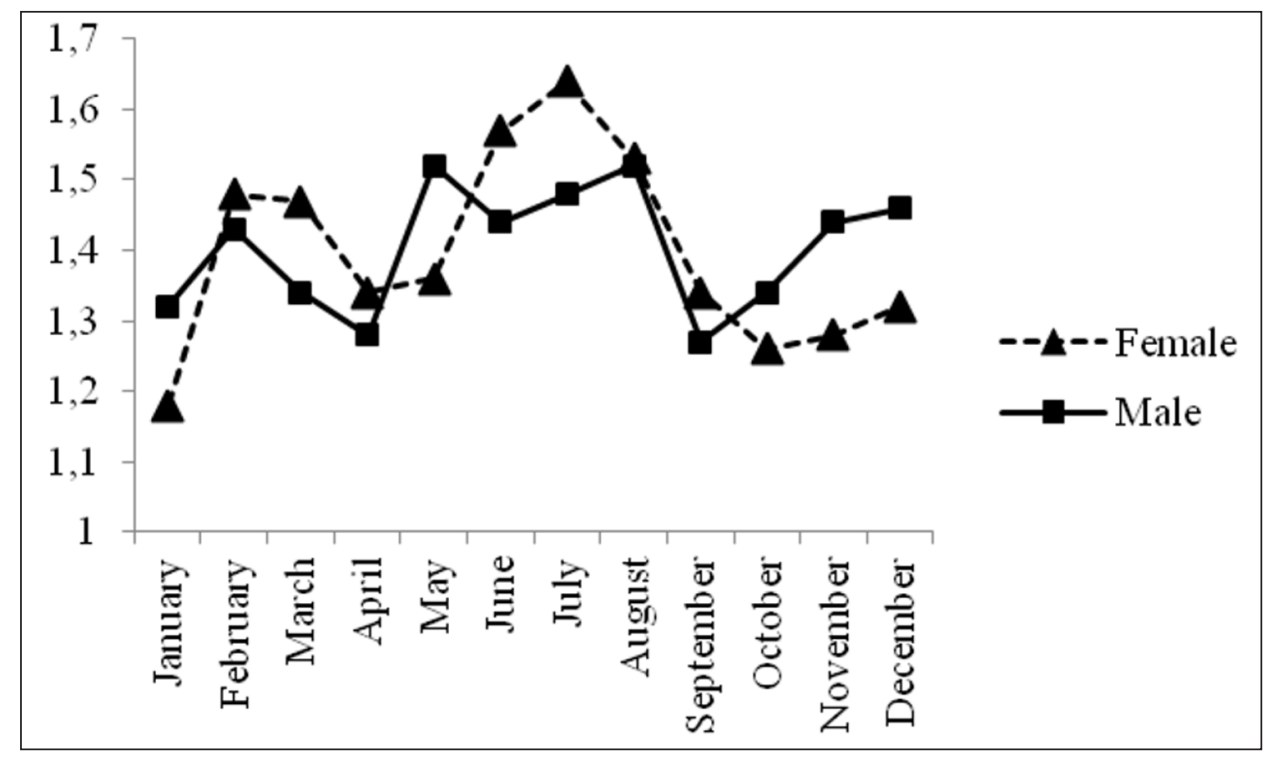

Fig. 5. Monthly variations in condition coefficient (CF) of L. cephalus

occurred between March and May, showing a peak in April. During spring (March-May) an obviously rapid growth of gonads occurred until next spawning.

A total of 431 chub individual was collected from Çaparlıpatlak Pond during the study period. In this study, among the specimens, female / male ratio was larger than 1 , as confirmed by the relevant literature (Türkmen et al., 1999; Saşı and Balık, 2003; Kara and Solak, 2004; Koc et al., 2007; Bostanc1 and Polat,
2009). Nikolsky (1963) indicates different sexual dispersions of the same species in different populations. It is well known that the sex ratio in most species is close to one, but it may vary from species to species, differing from one population to another of the same species and may vary year to year in the same population. The age of the chub caught in Çaparlipatlak Pond was between ages I and VI (Table 1). The fact that $60.55 \%$ of the specimens were in age III indicated that the population was

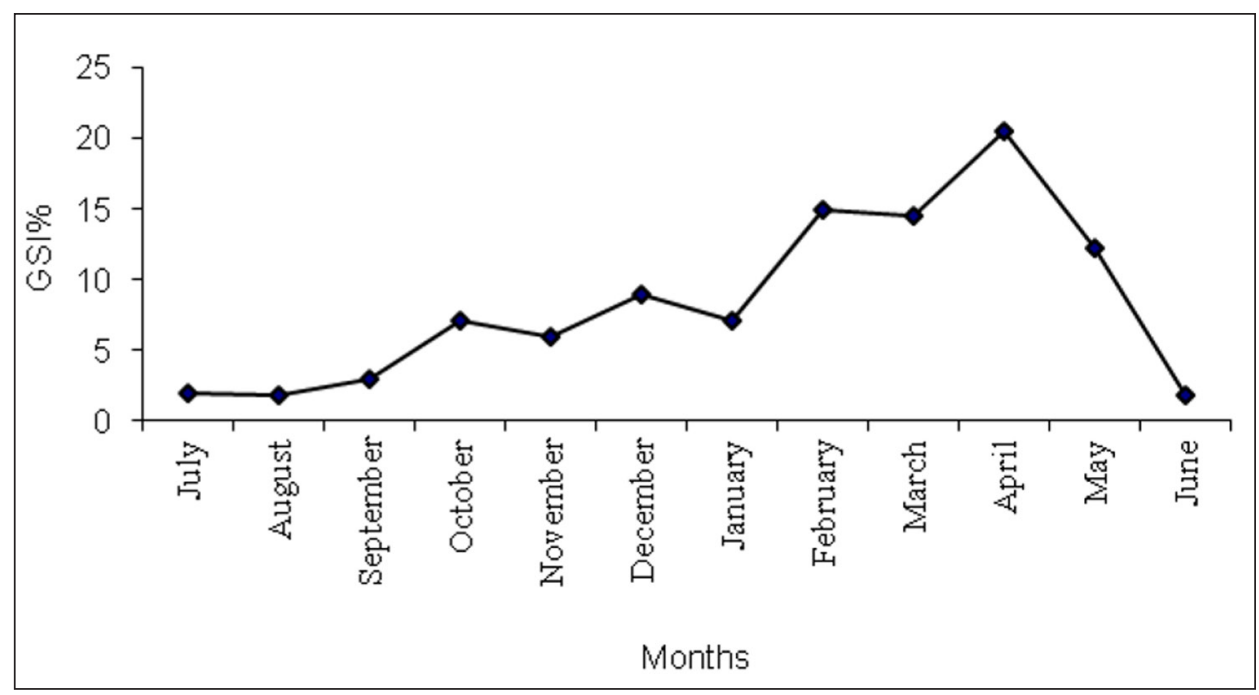

Fig. 6. Monthly variations in the GSI\% of L. cephalus 


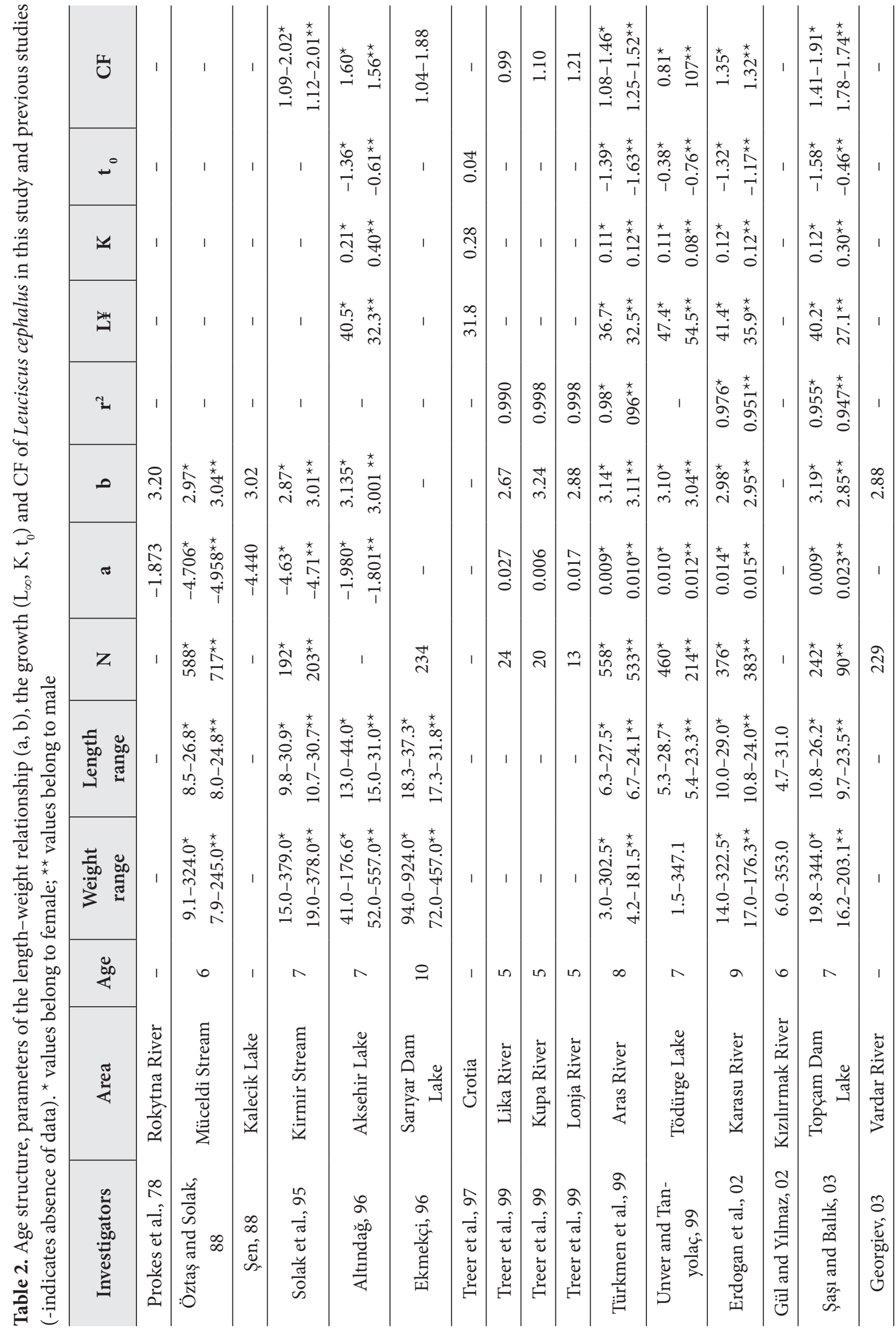




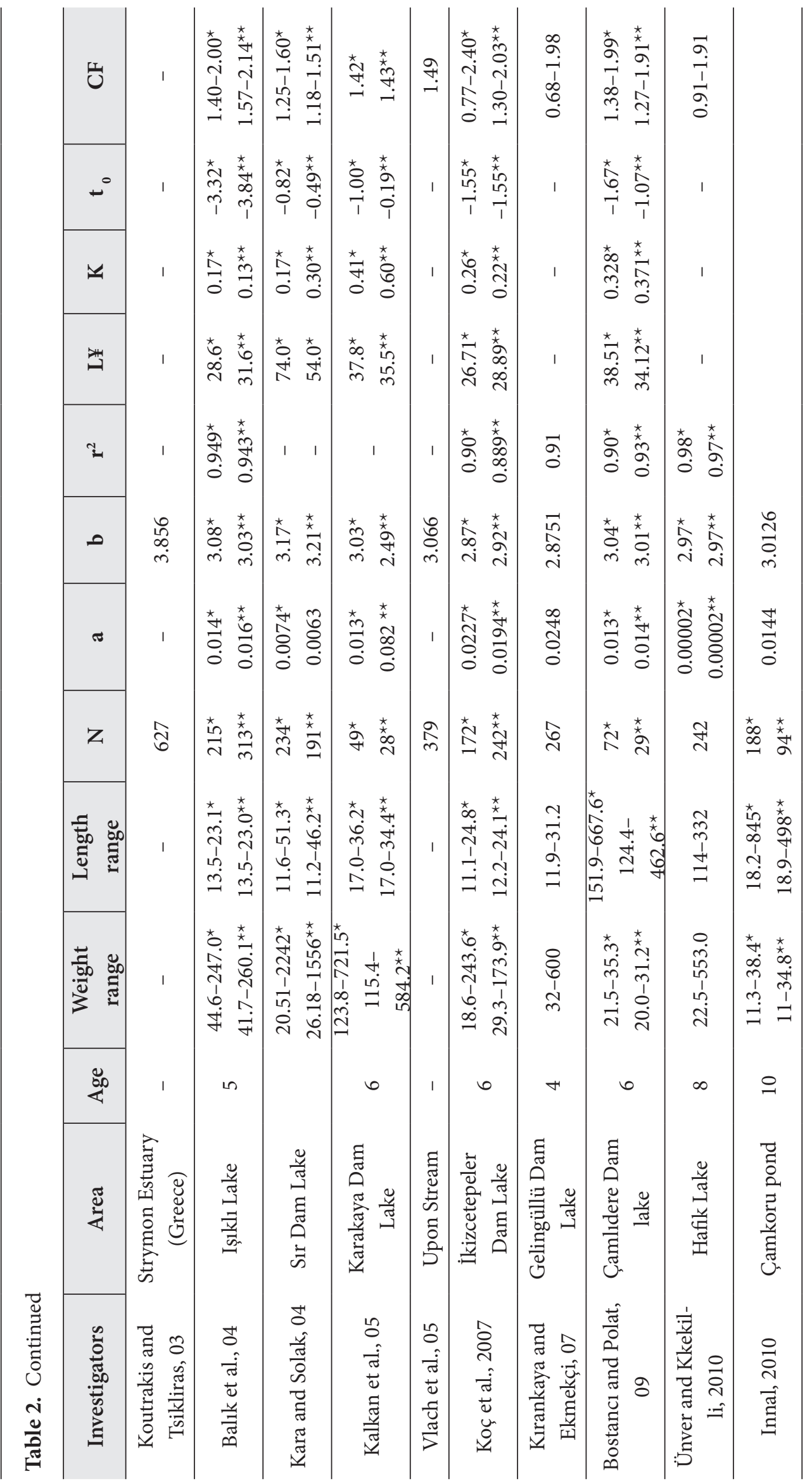


mostly made of young individuals, confirming the relevant study by Innal (2010). Age distributions in other investigations on this species are reported in Table 2 . The majority of samples in the population were in the third age group. This situation was also reported for Kirmir Stream population (Solak et al., 1995), while most of the samples were in the second age group (Altindag, 1996), were in the third age group (Ekmekçi, 1996) and in the second and third age groups (Kalkan et al., 2005). It is reported that most of the samples were in the third age group for Topçam, Karakaya, Almus and İkizcetepeler Dam Lake populations (Saşı and Balık, 2003; Kalkan et al., 2005; Koc et al., 2007). These differences in the age distribution of the populations may be due to gill net selectivity, fishing activity, feeding habits and the ecological characteristics of the lakes and reservoirs (Nikolsky, 1963). While males were longer and heavier in the earlier life stages than females, but in later stages females were longer and heavier than males. This situation was similiar to that reported by Altındag (1996), but it was different from that reported by some investigators in L. cephalus from Sariyer Dam Lake (Ekmekçi, 1996), Kirmir Stream (Solak et al., 1995), and Karakaya Dam Lake (Kalkan et al., 2005). $L \infty$ and $k$ values in Von Bertalanffy's growth equation can be used as indicators for making comparisons of growth (Sparre and Venema, 1992). A theoretical maximum length of $23.66 \mathrm{~cm}$ is realistic because the largest specimen sampled during the survey was $21.5 \mathrm{~cm}$. The theoretical maximum length and $\mathrm{k}$ value are close to those estimated for Dobra River in Crotia (Treer et al., 1997), Topçam Dam Lake (Saşı and Balık, 2003), and Upor Stream (Czech Republic) (Vlach et al., 2005). In contrast, Lobón-Cerviá (1982) finds that computed infinite lengths are smaller than sizes attained by the population. In our case, this is not so. Weight-at-age estimates were more valuable as a measure of growth length estimates. This variation may be due to different stages in ontogenetic development, as well as differences in condition, length, age, sex, and gonadal development (Ricker, 1975). Geographic location and some enviromental coditions such as temperature, organic matter, quality of food, data and time of capture, stomach fullness, disease, parasitic loads (Wooton, 1998) can also affect weight-at-age estimates. The condition coefficient changed according to months, age groups, and sexes (Türkmen et al., 1999; Bostanci and Polat, 2009; Altindag, 1996; Ekmekçi, 1996). In general, seasonal conditions showed a smiliar pattern in both sexes. Several investigators have reported similar patterns (Unver and Tanyolac, 1999; Erdogan et al., 2002). The slope (b) values of the length-weight relationships in female and male $(b=2.38,2.58)$ showed that weight increased negative allometrically with length. Our values of $b$ for Çaparlipatlak Pond were found to be close to those estimated in Warta River, Karakaya Dam Lake and Apa Dam Lake by Przyby (1996), Kalkan et al. (2005), but was different from those found by Altındag (1996), Türkmen et al. (1999), Erdogan et al. (2002), Solak et al. (1995), Balık et al. (2004), Bostanc1 and Polat (2009). The values $b$ are often 3.0 and generally between 2.5 and 3.5. The values $b$ in fish differ according to species, sex, age, seasons (Ricker, 1975). In addition, changes in fish shape, physiological conditions, during life span, growth increment or break can all affect the growth exponent b (Froese, 2006). Spawning occurred between March and May, showing a peak in April in Çaparlipatlak Pond population (Fig. 6). These are compared to the relevant studies (Table 3 ). In general, monthly conditions exhibited a similar pattern for both sexes, showing a peak before the spawning season, but indicating somewhat lower values after the spawning period and during winter (Fig. 6). Because the ecological and climatic conditions are different, the starting and finishing time of reproduction may include different months. As has been mentioned by a number of investigators, the spawning cycle is closely related to temperature. Spawning periods of fish vary with respect to their species; the ecological characteristics of fish are determined by such ecological differences as stagnant or running water, as well as altitude, temperature and quality of food (Nikolsky, 1963). 
Table 3. Spawning seasons of Leuciscus cephalus at various localities and average temperatures according to the previous studies

\begin{tabular}{|c|c|c|c|c|c|c|c|c|c|c|c|c|c|c|}
\hline \multirow{2}{*}{ References } & \multicolumn{12}{|c|}{ Months } & \multirow{2}{*}{ Locality } & \multirow{2}{*}{$\begin{array}{l}\text { Tem. } \\
\left({ }^{\circ} \mathrm{C}\right)\end{array}$} \\
\hline & $\mathrm{J}$ & $\mathrm{F}$ & M & A & M & $\mathrm{J}$ & $\mathbf{J}$ & A & $\mathrm{S}$ & $\mathrm{O}$ & $\mathrm{N}$ & $\mathrm{D}$ & & \\
\hline Hellawel (1971) & & & & & & & & & & & & & Afon Llynfi River & Low tem. \\
\hline Penaz et al., (1978) & & & & & & & & & & & & & Jihlava River & \\
\hline Erk’akan and Akgül (1986) & & & & & & & & & & & & & Kizılırmak River & \\
\hline Poncin et al., (1987) & & & & & & & & & & & & & - & \\
\hline Neophitou (1988) & & & & & & & & & & & & & Rentina River & \\
\hline Şen (1988) & & & & & & & & & & & & & Kalecik Reservoir & \\
\hline Öztaş (1989) & & & & & & & & & & & & & Müceldi Stream & $12-28^{\circ} \mathrm{C}$ \\
\hline Unlü and Balcı (1993) & & & & & & & & & & & & & Savur Stream & $15-23{ }^{\circ} \mathrm{C}$ \\
\hline Ekmekci (1996) & & & & & & & & & & & & & Sariyar Dam Lake & \\
\hline Altındağ (1997) & & & & & & & & & & & & & Akşehir Lake & \\
\hline Karatas (1997) & & & & & & & & & & & & & Tozanlı Stream & \\
\hline Karataş and Akyurt, 1997 & & & & & & & & & & & & & Almus Dam Lake & \\
\hline Yerli et al., (1997) & & & & & & & & & & & & & Çıldır Lake & \\
\hline Unver (1998) & & & & & & & & & & & & & Tödürge Lake & \\
\hline Türkmen et al., (1999) & & & & & & & & & & & & & Aras River & $16-23{ }^{\circ} \mathrm{C}$ \\
\hline Ylldırım et al., (2001) & & & & & & & & & & & & & Oltu Stream & $14-19^{\circ} \mathrm{C}$ \\
\hline Erdogan et al., (2002) & & & & & & & & & & & & & Karasu River & \\
\hline Fredrich et al., 2003 & & & & & & & & & & & & & Spree River & \\
\hline Kalkan et al., (2005) & & & & & & & & & & & & & Karakaya Dam & \\
\hline Koc TH et al., 2007 & & & & & & & & & & & & & İkizcetepeler Dam & $16-18{ }^{\circ} \mathrm{C}$ \\
\hline Lorenzoni et al., (2011) & & & & & & & & & & & & & Assino Creek & \\
\hline Unver and Saraydın (2012) & & & & & & & & & & & & & Tödürge Lake & \\
\hline This study (2005) & & & & & & & & & & & & & Çaparlıpatlak Pond & $7-27^{\circ} \mathrm{C}$ \\
\hline
\end{tabular}

\section{CONCLUSION}

The discharge of wastewater and sewage from the Bigadie Boron Works, reorganized as one of the subsidiaries of the Eti Mine Works in 2008, time to time into Çaparlipatlak Pond has caused irreversible damage to all life forms in the pond (Etimaden, 2014; Görmez, 1997). Therefore, necessary precautions and studies such as remediating wastewater to be discharded and the scheduling of the fishing seasons should be taken.

Received 28 May 2014 Accepted 09 September 2014

\section{References}

1. Altındag A. Some population characteristics growth and condition of chub (Leuciscus cephalus, Linne 1758) in Aksehir Lake. Tr J of Zool 1996; 20(Suppl.): 53-65.

2. Avsar D. Fishery biology and population dynamics. Univ. of Cukurova: Baki Press, Adana, Handbook 2005; 5: 303 pp.

3. Bagliniere JL, Le Louarn H. Caracteristiques Scalimetriques des Principales Especes de Poissons D'eau Douce de France. Bull Fr Peche Piscic 1987; 306: 1-39.

4. Balık S, Sarı HM, Ustaoglu SMR, Ilhan A. 
Age and growth properties of chub (Leuciscus cephalus L., 1758) population in Işıklı Lake (Çivril, Denizli, Turkey). EUJ Water Prod Fish 2004; 21: 257-62.

5. Bogutskaya NG. Contribution to the knowledge of Leuciscinae fishes of Asia Minor. Mitt Hamb Zool Mus Inst 1997; 94: 161-86.

6. Bostanci D, Polat N. Age Determination and Some Population Characteristics of Chub (Squalius cephalus L. 1758) in the Çamlidere Dam Lake (Ankara, Turkey). Turk J Sci \& Technol 2009; 4(1): 25-30.

7. Ekmekçi (Atalay) FG. Growth and reproduction properties of chub (Leuciscus cephalus, Linneaus 1758) in Saryyar Dam Lake, Tr J Zool 1996; 20(Suppl.): 5-106.

8. Emiroglu O, Cicek A, Arslan N, Aksan S, Rüzgar M. Boron Concentration in Water, Sediment and Different Organisms around Large Borate Deposits of Turkey. Bull Environ Contam Toxicol 2010; 84: 427-31.

9. Erdogan O, Türkmen M, Ylldırım A. Studies on the age, growth and reproduction characteristics of the chub, Leuciscus cephalus orientalis, (Nordmann, 1840) in Karasu River, Turkey. Turk J Vet Anim Sci 2002; 26: 983-91.

10. Etimaden. www.etimaden.gov.tr. Eti Mine Works, Annual Report, 2014.

11. Froese R. Cube law, condition factor and weight-length relationships: history, metaanalysis and recommendations. J Appl Ichthyol 2006; 22: 241-25.

12. Geldiay R, Balık S. Turkish freshwater fishes in Turkey, Univ. of Ege Univ. Fac of Water Prod., Izmir 2007; 46(5): 532 pp.

13. Görmez K. Enviromental problems and Turkey. Gazi Press 1997; 45(2) Ankara.

14. Gül A, Yllmaz M. Biological aspects of the chub, Leuciscus cephalus (L., 1758) living in Delice Stream, Kızılırmak. Univ Gazi J Sci Technol Instit 2002; 15(2): 485-94.

15. Hamwi N, Raikowa-Petrova GIK. Age and size composition of chub (Leuciscus cephalus L.) in the middle stream of the Iskar River, Bulgaria. Acta Zool Bulgaric 2005; 57: 363-70.
16. Innal D. Population Structures and Some Growth Properties of Three Cyprinid Species [Squalius cephalus (Linnaeus, 1758); Tinca tinca (Linnaeus, 1758) and Alburnus escherichii Steindachner, 1897] Living in Camkoru Pond (Ankara-Turkey). Kafkas Univ J Vet Fac 2010; 16(Suppl-B): 297-304.

17. Kalkan E, Yllmaz M, Erdemli AU. Some Biological Properties of the Leuciscus cephalus (L., 1758) Population Living in Karakaya Dam Lake in Malatya (Turkey). Turk J Vet Anim Sci 2005; 29: 49-58.

18. Kara C, Solak K. Some Biological Properties of Chondrostoma regium (Heckel, 1843) Inhabiting Sır Dam Lake (Kahramanmaraş), KSU J Sci Engineer 2004; 7(2): 13-9.

19. Karataş M, Akyurt I. The Reproduction Biology of Barbel (Barbus plebejus (Bonaparte, 1832) and Chub (Leuciscus cephalus, Linne 1758) in Almus Dam Lake. Turk J Vet Anim Sci 1997; 21: 345-53.

20. Koc HT, Erdogan Z, Tinkci M, Treer T. Age, growth and reproductive characteristics of chub, Leuciscus cephalus (L., 1758) in the Ikizcetepeler Dam Lake (Balikesir). J Appl Ichthyol 2007; 23: 19-24.

21. Kuru M. Vertebrates Book, Palme Press, Ankara: 2000, $841 \mathrm{pp}$.

22. Lobón-Cerviá J. Ecología de la ictiofauna del río Jarama. Ph. D. Thesis, University of Madrid, 1982.

23. Nikolsky GV. The ecology of fishes (Trans L. Birkett) Academic Press, London, 1963: $1-352$.

24. Pryzbiski M. Variation in fish growth characteristics along a river course. Hydrobiol 1996; 325(1): 39-46.

25. Ricker WE. Computation and interpretation of biological statistics of fish populations. Bull Fish Res Board Can 1975; 191: 382 p.

26. Saşı $\mathrm{H}$, Balık $\mathrm{S}$. Age, growth and sexual ratio of chub Leuciscus cephalus L., 1758 from Topçam Dam Lake. EU J Fish Aqu Sci 2003; 20 : 503-15.

27. Solak K, Gül A, Yılmaz M. A research on 
growing performations of Leuciscus cephalus (Linneaus, 1758) inhabiting Kirmir Stream (Ankara-Turkey), SDU. J of Water Prod Fish 1995; 4: 49-62.

28. Sparre P, Venema SC. Introduction to tropical fish stock assessment. Part 1. Manual. FAO Fisheries Technical Paper No 306. Rev. 1. Rome, FAO, 1992: 376 pp.

29. Treer T, Habekovic D, Anicic I, Safner R, Kolak A. Standard growth curve for chub (Leuciscus cephalus L., 1758) in Crotia. Ribarstvo 1997; 55(2): 47-52.

30. Türkmen MHI, Erdogan O, Yıldırım A. The growth and reproduction characteristics of chub Leuciscus cephalus orientalis (Nordmann, 1840) living in Aras River. Tr J Zool 1999; 23: 355-64.

31. Unver B, Tanyolac J. Growth properties of chub (Leuciscus cephalus L. 1758) in Lake Tödürge (Zara / Sivas). Tr J of Zool 1999; 23(Suppl 1): 257-270.

32. Vlach P, Dusek J, Svatora M, Moravec P. Growth analysis of chub, Leuciscus cephalus (L.), and dace, Leuciscus leuciscus (L.), in the Upor stream using growth data of recaptured marked fish. Czech J Animal Sci 2005; 50: 329-39.

33. Wooton RJ. Fish assemblage. In: Ecology of Teleost fishes, 2nd ed. Kluwer Academic, The Netherlands, 1998: 285 pp.
Hatice Torcu Koç, Zeliha Erdoğan, Kazım Bulgen

\section{EUROPINIO ŠAPALO (LEUCISCUS \\ CEPHALUS) BIOLOGINIŲ SAVYBIŲ \\ STEBE்JIMAS IR APLINKOS SĄLYGŲ \\ ITAKA ÇAPARLIPATLAK TVENKINYJE \\ (BALIKESYRAS, PIETŲ MARMARIO \\ REGIONAS, TURKIJA)}

\section{Santrauka}

Tyrimas atliktas su 431 Çaparlıpatlak tvenkinio individu, kurių amžius svyravo nuo I iki VI. Populiacijoje dominuojanti buvo IV amžiaus grupè. Patinèlių aptikta 36,60\%, patelių - 63,40\% (santykis 1:1.71). Patelès stambesnès nei patinèliai. Didžiausia pagauta patelè - 21,5 cm FL, didžiausias patinèlis - 20,2 cm FL (abu priklausè VI amžiaus grupei). Ilgio ir svorio santykis sieke $\mathrm{W}=0,0648 \cdot \mathrm{L}^{2,44}$ (W - mase g, FL - ilgis mm). Nustatytas Von Bertalanffy augimo lygis buvo $\mathrm{L}_{\infty}=23,66 \mathrm{~cm}$; $\mathrm{K}=0,30 \mathrm{yr}^{-1}$; to $=-0,95 \mathrm{yr}$. Makroskopinis lytiniu liaukų tyrimas ir gonadosomatinio indekso analize parodè, kad šapalai neršia pavasarị bei ankstyvą vasarą - balandžio ir liepos mèn., kai vandens temperatūra yra aukšta.

Raktažodžiai: Leuciscus cephalus, amžius, augimas, būklè, nerštas 